\title{
Marine gas hydrates' evolution after Middle Pleistocene: basin analysis of the Danube fan, Black Sea
}

\section{Еволюция на морски газови хидрати след Среден Плейстоцен: басейнов анализ на Дунавски фан, Черно море}

\author{
Atanas Vasilev ${ }^{1}$, Nikola Botoucharov', Petar Petsinski ${ }^{1}$, Rositsa Pehlivanova ${ }^{1}$ \\ Атанас Василев ${ }^{1}$, Никола Ботушаров ${ }^{2}$, Петър Пецински ${ }^{1}$, Росица Пехливанова ${ }^{1}$ \\ ${ }^{1}$ Институт по океанология - БАН, 9000 Варна; E-mail: gasberg@io-bas.bg \\ ${ }^{2}$ Софийски университет „Св. Климент Охридски“, 1504 София; E-mail: botnd@gea.uni-sofia.bg
}

\begin{abstract}
The aim of this work is to reconstruct the variations of the total gas hydrate (GH) masses of the Danube deep-sea fan after 0.265 Ma BP. The PetroMod ${ }^{\mathrm{TM}}$ model developed in GEOMAR, Germany is for basin analysis of the Western Black Sea for 98 Ma. Geological structure is from 2D seismic of the Black Sea consortium "Geology without limits". Results show a trend for total GH masses decrease after Middle Pleistocene and the role of the GHs as sink and source of methane.
\end{abstract}

Keywords: gas hydrates, gas seeps, methane, basin analysis, Black Sea.

\section{Въведение}

Газовите хидрати (ГХ) са едни от най-интригуващите и изучавани геоложки обекти днес. Само един процент от затворения в тях метан може да реши глобалния енергиен проблем в продължение на векове (Sloan, 2004) или да направи климата на планетата непоносим (Henriet, Mieneret, 1998).

Дълбоките води на Черно море са най-големия резервоар на метан и сероводород в света (Reeburgh et al., 1991) (87\% от обема на водното тяло). За пръв път природни ГХ са открити в Дунавския фан при геоложко опробване през 1972 г. (Yefremova, Zhizhchenko, 1974). Пояс от газови извори обгрыща латералната граница на зоната за стабилност на ГХ (ЗСГX; Vassilev, 2006).

Първото проучване на ГХ, основаващо се на идеите за басейнов анализ, е на Krason et al. (1985). Три години по-късно ГХ на Черно море стават част от същия проект, изследващ 21 перспективни за ГХ региона (Krason, Ciesnik, 1988). Първата оценка на емисиите на термогенен метан през дъното на Черно море в периода след кредната еволюция на басейна, е реализиран чрез историко-генетичен подход - басейнов анализ, разработен в Института по океанология - РAH (Vassilev, 2003). Последен, най-сьвременен и детайлен е модельт на ГХ в Черно море, създаден в GEOMAR (Burwicz, Haeckel, 2019) с PetroMod $^{\mathrm{TM}}$ (Schlumberger).
Първата оценка на обема метан в ГХ на Черно море е $6500 \mathrm{~km}^{3}$ или $\mathrm{bcm}\left(1 \mathrm{bcm}=1 \mathrm{~km}^{3}\right)$, а на средната дълбочина на долната граница на ЗСГХ 322 mbsf (Krason, Ciesnik, 1988). Оценката на Korsakov et al. (1989) е (20-25).103 $\mathrm{km}^{3}$. Vassilev (2006) с песимистичен и оптимистичен модели оценява метана в ГХ на Черно море на $(10-50) \cdot 10^{3} \mathrm{~km}^{3}$ и заключава, че песимистичният модел е характерен за абисалната част, а оптимистичният - за континенталния склон на басейна. Модел на изменение на ЗСГХ през последните 50 Ка показва намаляване на обема на ГХ резервуоар с 15-62\% след последния ледников максимум (ПЛМ) в Черно море (Poort et al., 2005).

Картите на газовите извори в Черно море показват, че повечето от тях изчезват на латералната граница на ЗСГХ и ширината на зоната с интензивни извори е пропорционална на ширината на прилежащия им шелф. „Температурен двигател“ на черноморските течения е широкият северозападен шелф. Там ниските зимни температури формират основния воден обем за басейна с повишена пльтност, способен да достигне по-значителна дълбочина и да поддържа бавните вертикални течения (Vassilev, 2003). Това е и зоната, където се очакват вай-съществени приливи на ЗСГХ. В района са открити наймащабните емисии на метан от над 2000 извора, граничещи с широка област с BSR - граница на 
сеизмичните записи между седименти с ГХ и със свободен газ (Ludmann et al., 2004).

\section{Резултати}

Районът на това изследване е дълбоководната палеоделта на Дунав, включваща най-северната част на Българската изключителна икономическа зона на Черно море (БИИЗ; фиг. 1). Там, южно от каньона Витяз, са открити уникални находища на кратни BSR в най-младото погребано русло на Дунав (Рopescu et al., 2006). Районът на Дунавската палеоделта е определен като най-обещаващият в Европа за внедряване на технологии и добив на метан от ГХ заради очакваните пясъчни колектори и промишлени ресурси (Bialas et al., 2014).

Реализираният басейнов анализ, симулиращ $98 \mathrm{Mа} \mathrm{еволюция} \mathrm{на} \mathrm{басейна} \mathrm{на} \mathrm{Черно} \mathrm{море,} \mathrm{е} \mathrm{де-}$ тайлно описан от Burwicz \& Haeckel (2019). Използваният геоложки строеж е резултат от изследване на консорциум от черноморски държави по програма „Геология без граници“ на дълбочинния строеж на басейна с многоканална 2D сеизмика със запис на трасе 18 s (Nikishin et al., 2003). Новите резултати, представени в Табл. 1, са получени със съвременни теоретични, програмни и изчислителни средства, които решават система от дузина диференциални уравнения с начални, гранични условия и параметри, получени от интензивни мултидисциплинарни изследвания на ГХ в района през последните 20 години.

За 5 денонощия на работните станции в GEOMAR успешно преминаха 5 симулации.

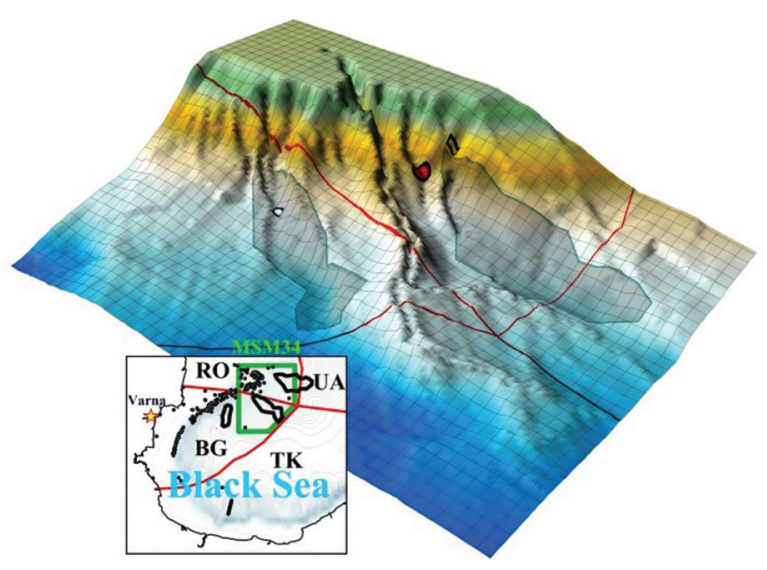

Фиг. 1. Батиметрична карта на района на палеоделтата на Дунав и каньон Витяз: затъмнени полигони в българската и румънската ИИЗ - площи, на които са открити BSR, показващи 2 перспективни ГX находища (Popescu et al., 2006); червени линии - граници на ИИЗ; батиметрия от многолъчеви ехолоти с размер на пиксел $25 \mathrm{~m}$ (проекти ASSEMBLAGE, EC и SUGAR, FRG); правоъгълни полигони в BSR площите - детайлни 3D сеизмични, електромагнитни измервания; червен флаг - второто по ресурси газово находище в Черно море -Домино, Румънска ИИЗ.
Основните резултати са записани в 4000 файла (около 7\% от всички резултати) в картни формати за целите на проект ГЕОХидрат. Дискутираните тук резултати за измененията на масата на ГХ (в Mt) през последните $265 \mathrm{Ka}$, са представени на 9 карти в проекция WGS84 UTM36N. Моделната площ е $67000 \mathrm{~km}^{2}$, а изчислителната мрежа е с 7821 точки $(79 \times 99)$. Х-стьпката е 2733 m, Y-стьпката 3205 m, а Z и t (стьпката по време), са променливи за достигане на зададена точност. Тези карти показват, че ГХ се формират основно на континенталния склон.

За изчисления на стойностите в Табл. 1 са използвани: а) плътност на метановите хидрати $0.9 \mathrm{~g} / \mathrm{cm}^{3}$ (Max, 2003); б) един обем метанов хидрат съдържа 164 обема метан при стандартно налягане и температура (SPT) (Ruppel, 2011); в) плътност на метана 0,717 g/l (van Amstel, 2012).

Максимален е обемът на ГХ преди $159 \mathrm{Ka}-$ $441 \mathrm{~km}^{3}$. Оттогава този обем намалява и днес е повече от 2 пъти по-мальк. Моделът показва ускорено намаляване на обема на ГХ след ПЛМ със скорост на изменение 4-кратно по-висока през последните $10 \mathrm{Ka}$. Максималната средна скорост на намаляване на обема на ГХ е с 26\% по-висока от съвременната и се отнася за периода 6-2 Ка ВР. Единствено в периода 2-1 Ка ВР модельт отчита увеличение на обема на ГХ с 1\%.

\section{Дискусия}

За сравнение на новите с вече публикуваните резултати отчитаме площите на: Черно море (420 $800 \mathrm{~km}^{2}$ ); БИИЗ (43 $860 \mathrm{~km}^{2}$; 10\% от площта на Черно море); континенталния склон на Черно море (106 $100 \mathrm{~km}^{2}$ ); склона на БИИЗ (9380 km²; $\sim 9 \%$ от площта на континенталния склон на Черно море). Площта на PetroModтм модела е $66960 \mathrm{~km}^{2}$ или $\sim 16 \%$ от тази на Черно море и $\sim 66 \%$ от БИИЗ и 7 пъти по-голяма от площта на континенталния склон на БИИЗ.

Резултатите от модела показват стабилна тенденция на намаляване на общата маса на ГХ за последните $100 \mathrm{Ka} \mathrm{c} \mathrm{едно} \mathrm{изключение} \mathrm{след}$ ПЛМ, когато преди 1 Ка масата на ГХ се увеличава с $1 \%$. Това увеличение е хипотетично, но е възможно като следствие от формиране на съвременния циркулационен модел на теченията.

Резултатите в Табл. 1 са съпоставими с тези от оптимистично-песимистичния модел на Vassilev (2006) и с резултатите, отчитащи намаляване на обема на ГХ резервоар с 15-62\% след ПЛМ, поради започналите преди 7,1 Ка изменения на климата, морското ниво и солеността на Черно море (Poort et al., 2005).

Новите резултати са близки и до оценката на емисиите от термогенен метан през дъното на басейна през последните $65 \mathrm{Ma}$, определи- 
Таблииа 1. Изменение на масата и обема на ГХ в моделния район за последните 265 Ка

\begin{tabular}{|c|c|c|c|c|c|c|c|c|}
\hline $\begin{array}{c}\mathrm{T} \\
(\mathrm{Ka})\end{array}$ & $\begin{array}{c}\mathrm{dt} \\
(\mathrm{Ka})\end{array}$ & $\begin{array}{c}\text { ГXM } \\
\max \\
(\mathrm{Mt} / \mathrm{cell})\end{array}$ & $\begin{array}{c}\text { ГХМ } \\
\text { средна } \\
\text { (Mt/cell) }\end{array}$ & $\begin{array}{c}\text { ГХМ } \\
\text { средна } \\
\left(\mathrm{m}^{3} / \mathrm{m}^{2}\right)\end{array}$ & $\begin{array}{c}\Gamma \mathrm{X} \\
\text { обем } \\
\left(\mathrm{km}^{3}\right)\end{array}$ & $\begin{array}{c}\text { Промяна } \\
\text { ГХ обем } \\
\left(\mathrm{km}^{3}\right)\end{array}$ & $\begin{array}{c}\text { Промяна } \\
\mathrm{CH}_{4} \text { обем } \\
\left(\mathrm{km}^{3}\right)\end{array}$ & $\begin{array}{c}\text { Промяна } \\
\mathrm{CH}_{4} \text { обем } \\
\left(\mathrm{km}^{3} / \mathrm{a}\right)\end{array}$ \\
\hline 0 & 1 & 849.7 & 22.82 & 2.89 & 198 & -7 & 1073 & 1.07 \\
\hline 1 & 1 & 849.6 & 23.58 & 2.99 & 205 & 2 & & \\
\hline 2 & 4 & 849.5 & 23.33 & 2.96 & 203 & -33 & 5387 & 1.35 \\
\hline 6 & 4 & 902.2 & 27.11 & 3.44 & 236 & -24 & 3913 & 0.98 \\
\hline 10 & 16 & 939.5 & 29.86 & 3.79 & 259 & -26 & 4280 & 0.27 \\
\hline 26 & 27 & 935.6 & 32.86 & 4.17 & 286 & -25 & 4162 & 0.15 \\
\hline 53 & 53 & 907.1 & 35.78 & 4.54 & 311 & -84 & 13832 & 0.26 \\
\hline 106 & 26 & 1154.6 & 45.49 & 5.77 & 395 & -28 & 4515 & 0.17 \\
\hline 132 & 27 & 1737.1 & 48.65 & 6.17 & 423 & -19 & 3046 & 0.11 \\
\hline 159 & 53 & 1730.0 & 50.79 & 6.44 & 441 & 37 & & \\
\hline 212 & 53 & 1722.3 & 46.59 & 5.91 & 405 & & & \\
\hline 265 & & 1160.3 & 24.73 & 3.14 & & & & \\
\hline
\end{tabular}

T, Ка - възраст на оценката; dt, Ка - стъпка по време (разлика на съседни възрасти); ГХМ, Mt/cell - маса на ГХ на площ 1 клетка от изчислителната мрежа (2733 х 3205 m); Промяна CH4 обем, $\mathrm{km}^{3} / \mathrm{a}$ - годишно изменение на обема на метана в общата маса на ГХ.

ла средните емисии през Неозоя на $0,0007 \mathrm{Tg} / \mathrm{a}$ (Vassilev, 2003) или $\sim 1 \mathrm{~km}^{3} /$ а (виж стойността за $\mathrm{t}=0$ в Табл. 1 , колона Промяна $\mathrm{CH}_{4}$ обем $\left.\mathrm{km}^{3} / \mathrm{a}\right)$.

\section{Заключение}

Разработеният в GEOMAR c PetroMod ${ }^{\mathrm{TM}}$ (Schlumberger) модел за басейнов анализ на западната част на Черно море предоставя възможност за проверка на хипотези и изследване на детайли във вариациите на ГХ през геоложката еволюция на басейна. Представените 9 резултата за изменението на масата на ГХ през последните $265 \mathrm{Ka}$ от формирането на северозападната част на Черно море, показват ясна тенденция за намаляване на ГХ. Район на значителни изменения е континенталният склон, където в план ЗСГХ отстъпва на изток и става по-дълбоководна, при което западната половина на площта с ГХ постепено изчезва през последните $159 \mathrm{Ka}$. Намалява и масата на ГХ на единица площ. Основната част от освободения метан подхранва мащабни емисии през морското дъно.

Благодарности: Изследването е по проект КП-06-ОПР 04/7 от 18.12.2018 ГЕОХидрат „Геотермична еволюция на морски находища на газови хидрати - палеоделтата на Дунав, Черно море“, финансиран от Фонд „Научни изследвания“ на Министерството на образованието и науката. Авторите благодарят на Dr Ewa Burwicz, GEOMAR, без чиято помощ получаването на тези резултати беше невъзможно.

\section{Литература References}

Bialas J., I. Klaucke, M. Haeckel. 2014. Report No 15, MSM Cruise 34, Leg $1 \& 2$, SUGAR site, $111 \mathrm{p}$.
Burwicz, E., M. Haeckel. 2019. Basin-scale estimates on the petroleum components generation in the Western Black Sea basin based on the 3-D numerical model. - Mar. Pet. Geol., 104-122.

Henriet, J. P., J. Mieneret. 1998. Gas Hydrates - Relevance to Word Margin Stability and Climatic Change. England, Geol. Soc. Spec. Publ. 137, 348 p.

Korsakov, O., Yu. Byakov, S. Stupak. 1989. Gas hydrates of the Black Sea Basin. - Sov. Geologia, 12, 3-10 (in Russian with English abstract).

Krason, J., M. S. Ciesnik, 1988. Basin analysis, formation and stability of gas hydrates in the Black Sea. - Geological Evolution and Analysis of Confirmed or Suspected Gas Hydrate Localities, 11, US DOE/MC/21181-1950 (DE80001057), 88 p.

Krason, J., P. Finley, B. Rudloff, 1985. Basin analysis, formation and stability of gas hydrates in the western Gulf of Mexico. - Geological Evolution and Analysis of Confirmed or Suspected Gas Hydrate Localities, 3, 167 p.

Lüdmann, T., H. Wong, P. Konerding, M. Zilmer, J. Petersem, E. Fluh. 2004. Heat flow and quantity of methane deduced from a gas hydrate field in the vicinity of the Dnieper Canyon, northwestern Black Sea. - Geo-Mar. Lett., 24, 182-193.

Max, M. D. 2003. Natural Gas Hydrate in Oceanic and Permafrost Environments. Kluwer A. P., 62 p.

Nikishin, A., M. Korotaev, A. Ershov, M.-F. Brunet. 2003. The Black Sea basin: tectonic history and Neogene-Quaternary rapid subsidence modelling. - Sed. Geol., 156, 1, 149-168.

Poort, J., A. Vassilev, L. Dimitrov, 2005. Did postglacial catastrophic flooding trigger massive changes in the Black Sea gas hydrate reservoir? - Terra Nova, 17, 2, 135-140.

Popescu, I., M. De Batist, G. Lericolais, H. Nouzé, J. Poort, N. Panin, W. Versteeg, H. Gillet. 2006. Multiple bottom-simulating reflections in the Black Sea: potential proxies of past climate conditions. - Mar. Geol., 227, 163-176.

Reeburgh, W., B. Ward, S. Whalen, K. Kerkhof. 1991. Black Sea methane geochemistry. - Deep-Sea Res., 38, Suppl. 2, 1189-1210.

Ruppel, C. D. 2011. Methane hydrates and contemporary climate change. - Nature Edu. Knowl., 3, 10-29.

Sloan, E. D. 2004. Introductory overview: Hydrate knowledge development. - Am. Mineral., 89, 1155-1161.

van Amstel, A. 2012. Methane. A review. - J. Integr. Env. Sci., 9, Sup1., 5-30.

Vassilev, A., 2003. Black Sea Basin: 65 million years methane breath. - C. R. Acad. Bulg., 56, 3, 9-14.

Vassilev, A., 2006. Optimistic and pessimistic model assessments of the Black Sea gas hydrates. - C. R. Acad. Bulg., 59, 5, 543-550.

Yefremova, A. G., B. P. Zhizhchenko, 1974. Occurrence of crystal hydrates of gases in sediments of modern marine basins. - Dokl. Akad. Nauk SSSR, Earth Sci. Sect., 214, 5, 1179-1181 (in Russian). 